\title{
Late Pleistocene invasion of Palaeo-Dead Sea into the lower Zin Valley, the Negev Highlands, Israel
}

\author{
V. S. Sheinkman \\ Ramon Science Center, Blaustein Institute for Desert Research, Ben-Gurion University of the Negev, P.O.B. 194, Mizpe \\ Ramon, 80600 Israel \\ (Email: sheinkma@bgumail.bgu.ac.il)
}

Received: 16 October 2000 - Revised: 15 October 2001 - Accepted: 11 April 2002

\begin{abstract}
Evidence of invasion of Lake Lisan, the Late Pleistocene precursor of the Dead Sea, is revealed within the valley of lower Nahal Zin that runs down to the Dead Sea from the Negev Highlands. The main proof of the invasion is presence of lacustrine sediments that are followed continuously along the Lower Zin valley for a distance of $25 \mathrm{~km}$ from the coast of the Dead Sea. Extending deep into the interior of the Nahal Zin valley, the lacustrine sediments are included in the terraces at relative heights of 16 and $28-32 \mathrm{~m}$. They overlay alluvial bases of the terraces or interbed in alluvial deposits. TL dating has demonstrated that age of the lacustrine sediments is of about $30 \mathrm{Ka}$. TL ages of the deposits forming the alluvial bases of the terraces, which are covered by the lacustrine sediments, are of 40 to $60 \mathrm{Ka}$. Otherwise Pleistocene lacustrine sediments both in younger and older age are absent in the terrace sections of the Zin valley. The revealed lacustrine sediments are uppermost, known of this kind. They are tapered out at $-130 \mathrm{~m}$ altitude, and deposed during the highest stand of Lake Lisan, which is correlated with the marine isotope stage 2. Other fluctuations in the level of the Dead Sea and its Pleistocene precursors also exerted an influence on the development of the Zin valley. However their evidence occurs only in the Dead Sea tectonic basin except of the deep interior of the valley.
\end{abstract}

\section{Introduction}

During the Late Quaternary, Lake Lisan occupied the lowest part of the Dead Sea tectonic basin. This precursor of the Dead Sea underwent a significant change. Its volume was increased several times in comparison to the modern lake (Neev and Emery, 1967; Begin et al., 1974, 1985; Yechieli et al., 1992, 1998; Niemi et al., 1997). Lake Lisan left wellpreserved evidence of its geological effect that was appeared by filling the former bottom of the lake with well-expressed lacustrine sediments, and forming wave-cut terraces. These evidences allow researchers to reconstruct Palaeo-Dead Sea.

The sediments of Lake Lisan were unified as the Lisan formation (Neev and Emery, 1967; Begin et al., 1974). In the best way, the Lisan deposits are studied within the terrain between the Dead Sea shore and a fault escarpment that bounds the Dead Sea tectonic basin to the west, where they cover the former bottom of Palaeo-Dead Sea by whitish sediments characterized by thin varves.

Within the Dead Sea tectonic basin, the Lisan sediments are underlain by lacustrine deposits of the Samra Formation. The age of the oldest Lisan sediments at the Lisan-Samra boundary was determined by U/Th method to be about $70 \mathrm{Ka}$, and the ages of the youngest Lisan sediments are of 11 to $13 \mathrm{Ka}$ (Kaufman, 1971; Neev and Hall, 1977; Kaufman et al., 1992; Stein et al., 1997). Exposures of the Lisan sediments extend to Lake Tiberias in the north, and to Hazeva in the south.

In 1967 Neev and Emery presented the first sound summary of data about ancient lakes formed within the Dead Sea tectonic basin. They defined the uppermost stand of Lake Lisan at $-180 \mathrm{~m}$ altitude. This value is based on the top elevation of the Lisan marls that reach its maximal level in the Hazeva region. Since then, the value $-180 \mathrm{~m}$ has been accepted as the maximal level for Lake Lisan by most of researchers (Horowitz, 1979; Begin et al., 1985; Bar-Yosef and Kra, 1994; Niemi et al., 1997).

However, in the Wadi El-Hasa (southern-eastern part of the former basin of Lake Lisan) Clark (1988) revealed that the marls elevate to $-160 \mathrm{~m}$ altitudes. Bowman and Gross (1992) argued that the maximal level of Lake Lisan raised still higher, because they have revealed lakeshore terraces and beach bars of Palaeo-Dead Sea within the Hazeva area at $-150 \mathrm{~m}$ altitude. In 2001, Y. Bartov in his lecture (Annual Meeting of Israel Geological Society) has reported that new data within the Dead Sea tectonic basin demonstrate that the 


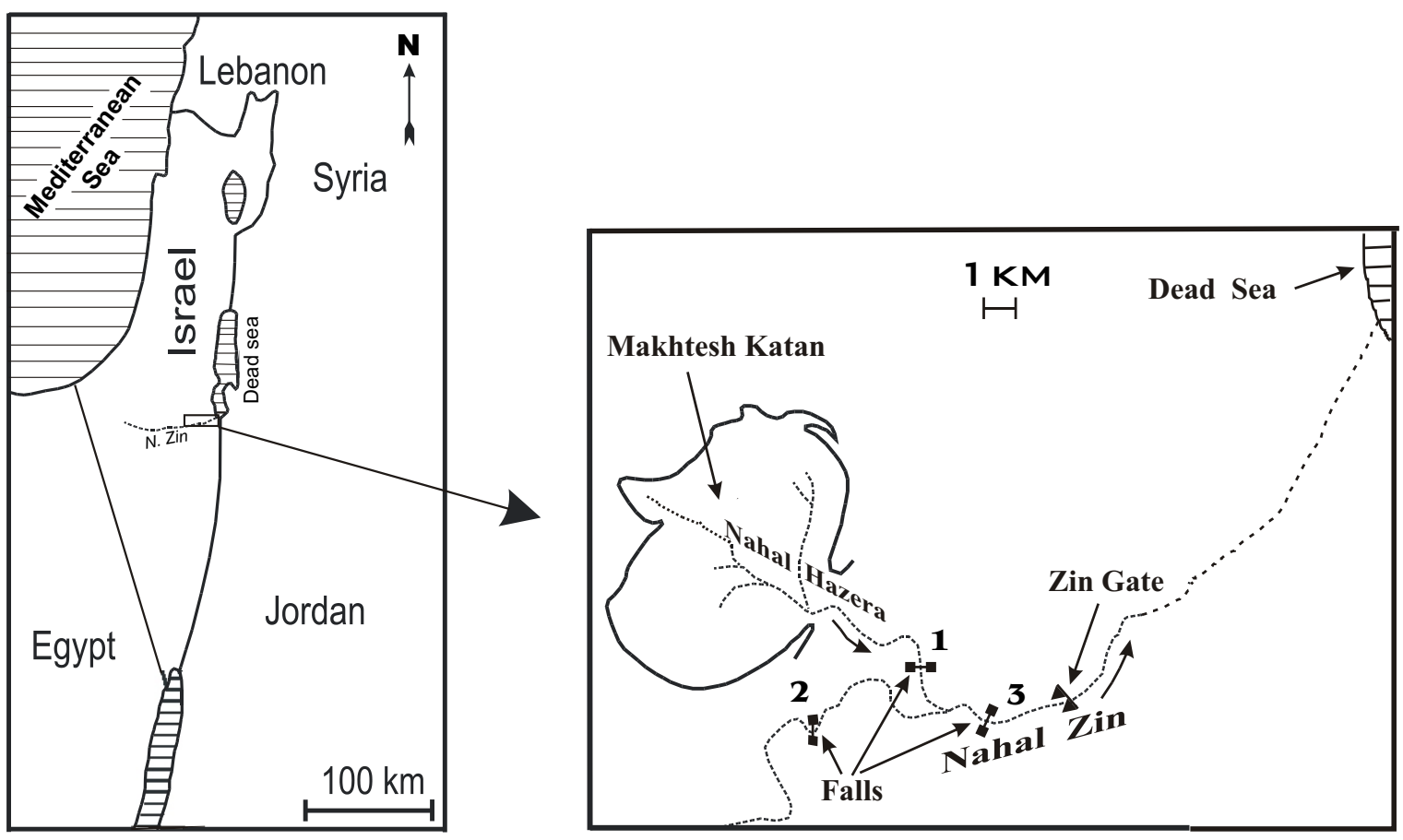

Fig. 1. Location map; 1 - Hazera Falls, 2 - Upper Zin Falls, 3 - Lower Zin Falls.

maximal level of Lake Lisan may be raised to $-164 \mathrm{~m}$.

Hitherto, study of the Lake Lisan deposits did not touch areas outside the Dead Sea tectonic basin. However, lake water should be invaded deep into the valleys, running to that basin, even in the case of $-180 \mathrm{~m}$ stand of Palaeo-Dead Sea. (For example, a contour line $-180 \mathrm{~m}$ crosses the gorgeshaped portion of the Nahal Zin valley a few kilometers upstream from the rock-steep framework of the Dead Sea tectonic basin). We began to search evidence of a potential invasion of lake water in the valleys, running to the Dead Sea, and already initial observations (Sheinkman, 2000a) allow us to reveal there numerous relics of great bays of Palaeo-Dead Sea.

The best representative, which demonstrates proofs of invasion of Palaeo-Dead Sea into the valleys upstream of the rock-steep bounds of the Dead Sea tectonic basin, turned out to be the valley of lower Nahal Zin. At that, in the best way, the evidence of the invasion is expressed along the Nahal Hazera - Nahal Zin valley system. Concentrating our efforts to study this valley system, we revealed that the Lisan lacustrine sediments raised to $-130 \mathrm{~m}$ altitude (Sheinkman, 2000a, 2000b).

\section{Study area and its geomorphologic units}

Nahal Zin (Southern Israel) crosses the Negev Highlands (altitudes to $1000 \mathrm{~m}$ above sea level) in sub-latitudinal direction, and flows into the Dead Sea ( $415 \mathrm{~m}$ below sea level). The river system of lower Nahal Zin drains the eastern flanks of the Negev Highlands, and the southwestern part of the Dead
Sea tectonic basin. The main tributary of lower Nahal Zin is Nahal Hazera that has its source from the Makhtesh Katan (Fig. 1).

The network of lower Nahal Zin is developed under hyperarid conditions, when the annual average evaporation is of about $2000 \mathrm{~mm}$ whereas the annual average precipitation is less than $100 \mathrm{~mm}$ (Brawer, 1992). Within the Dead Sea tectonic basin, the network is cut into the marly sediments of Lake Lisan. Upstream of the fault escarpment, which bounds the Dead Sea tectonic basin to the west, Nahal Zin cut into bedrocks, and develops a gorge-shaped valley. The boundary between the plain reach and the mountainous reach of the valley is marked by the exit of Nahal Zin from its rocky canyon into the expanse of the Dead Sea tectonic basin. We name this place "Zin Gate" (Fig. 1).

The base level of erosion of Nahal Zin is situated at the Dead Sea, and, therefore, change in position of the lake has to control geomorphologic processes in the Zin valley. The same role was played by precursors of the Dead Sea, which periodically invaded into the valley, and controlled erosiveaccumulative processes there.

At present, the controlling influence of the Dead Sea on the Zin valley is limited. It is conditioned by development of dry waterfalls in the riverbed of the gorge-shaped valley. The falls are composed of hard carbonate rocks. After their creation, they became to fulfill the role of knickpoints, and dump out the controlling effect of the certain lakes that could be located within the Dead Sea tectonic basin later on. It is seen to be from the riverbed profile constructed along the Nahal Hazera-Nahal Zin river system (Fig. 2). 


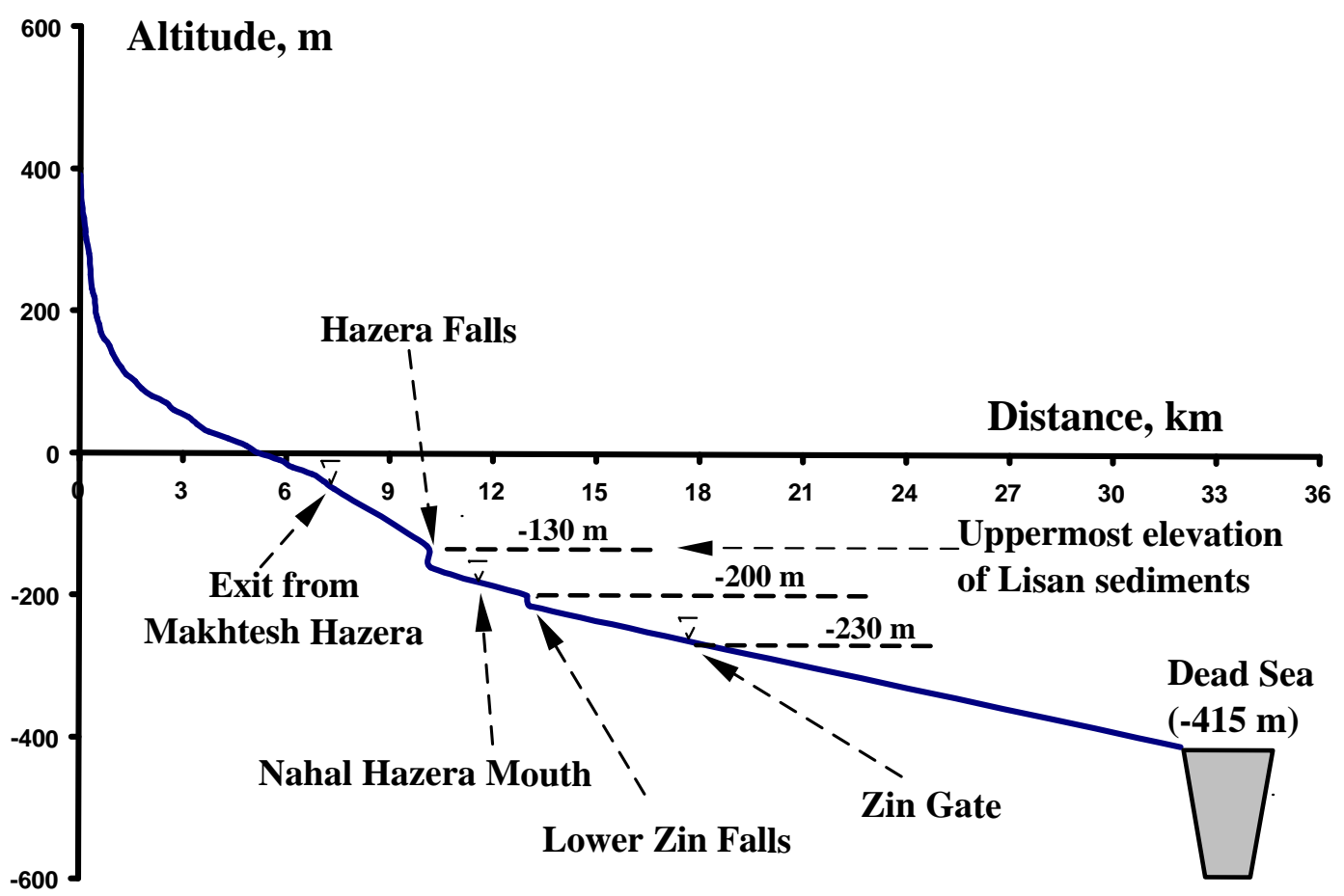

Fig. 2. The riverbed profile along the Nahal Hazera-Zin system.

On the whole, this profile is closed to an equilibrium profile except of breaks appeared as the falls. Even the exit of Nahal Hazera from Makhtesh Katan is marked by small change in the profile. The most probable phenomenon that causes development of the falls is regressive erosion triggered by changes in the base level of erosion, because the position of the falls shows that no tectonic disturbance or other similar geological processes causing their construction.

The first falls, $16 \mathrm{~m}$ in height, are situated $2 \mathrm{~km}$ upstream from the Zin Gate (Figs. 1, 2). We name it "Lower Zin Falls". Two other falls, about $30 \mathrm{~m}$ in height, are respectively located in the main Zin valley, and in the valley of its tributary, Nahal Hazera (Fig. 1). In the Hazera valley, the falls are located $1.5 \mathrm{~km}$ upstream from the confluence of Nahal Hazera with Nahal Zin. In the main Zin valley, the falls are located $6 \mathrm{~km}$ upstream from the confluence. We name them respectively "Hazera Falls" and "Upper Zin Falls" (Figs. 1, 2).

The Hazera Falls are one steep unit, whereas the Upper Zin Falls are a cascade made up of a series steep falls. The edges of both falls are situated at the same altitudes of -120 to $-130 \mathrm{~m}$. This may stand for indication of an ancient denudation surface, in which the present-day valley of lower Nahal Zin is cut.

Three noted falls and the Zin Gate turned out the fixed points that demarcate the valley of lower Nahal Zin according to the certain influence exerted on it by the Dead Sea and its precursors. Under this influence, distinct portions of the Lower Zin valley have taken on specific features, according to which some geomorphologic units may be distinguished along lower Nahal Zin.

The reach of the Zin valley within the terrain of the Dead
Sea tectonic basin, $17 \mathrm{~km}$ in length, may be unified as a single geomorphologic unit. At the Zin Gate, the riverbed is located at $-230 \mathrm{~m}$ altitude, and most of changes in the level of Palaeo-Dead Sea could influence on the Zin valley till these altitudes. It is expressed in alternating lacustrine and fluvial deposits in this portion of the valley.

Three units more have to be distinguished within the gorge-shaped valley of lower Nahal Zin. The first of them is the reach where the deposits of Lake Lisan are already not revealed. It occurs upstream of the falls that break the riverbeds of Nahal Zin and Nahal Hazera at -120 to $-130 \mathrm{~m}$ altitudes.

The second unit is the reach stretched downstream of those falls till the Lower Zin Falls. This valley portion is characterized by presence of lacustrine sediments that were defined (Sheinkman, 2000a, 2000b) as the deposed during the highest stand of Lake Lisan.

The third unit is the reach between the Lower Zin Falls and the Zin Gate. Lacustrine sediments are mainly presented there as the deposed during the highest stand of Lake Lisan. However, near the Zin Gate evidence of invasion of lake water during otherwise stage of Palaeo-Dead Sea occurs.

\section{Methods}

To solve the raised problem we needed to ascertain geomorphologic development of each distinguished portions of the Zin valley. For this purpose, terraces were identified along the dry riverbeds, and classified into staircase members according to their height above the floor of the related active 


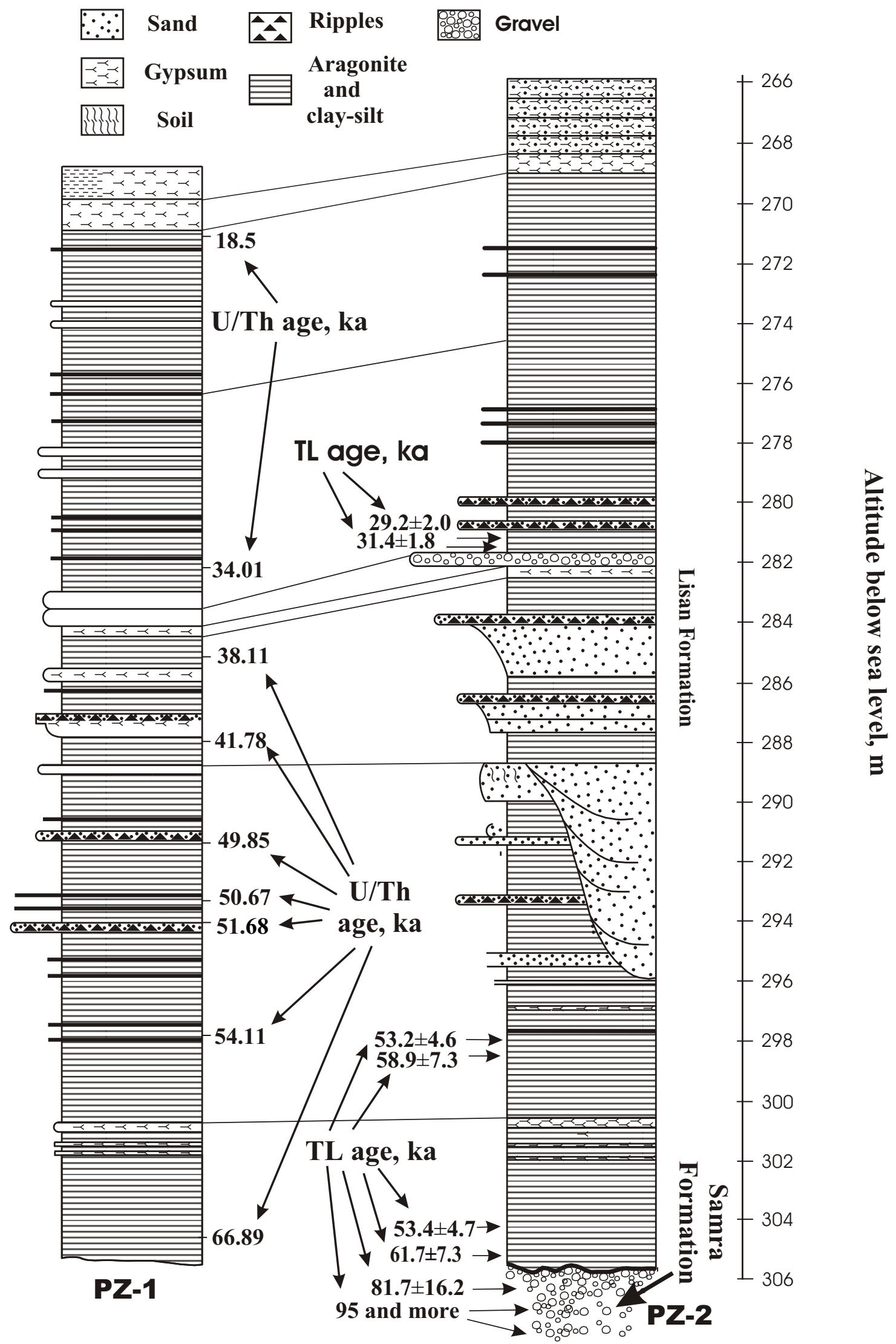

Fig. 3. The PZ-1 and PZ-2 sections (after Machlus et al., 2000) and their dating. 
dry riverbed. Sediment samples were collected from terrace sections, and the quartz grains were dated by thermoluminescent (TL) dating method.

We have applied a new speeded-up variation of TL dating, the S-S technique (Shlukov et al., 1999; Sheinkman and Shlukov, 2001). TL method is a way of dosimetric dating that is based on the property of the certain minerals (quartz, feldspar) to accumulate energy of background radiation, and to emit it under heating as a TL signal. A dose of accumulated/emitted energy is time function, and the age of a studied sample is calculated as compared of the TL signal obtained for the sample to both the saturation signal and the zeroing signal. The zeroing signal is attained by exposing the sample to sunrays. The saturation signal may be obtained by two ways. The traditional technology of TL dating (Wintle, 1997) applies a labor-capacious procedure of individual calibration of samples under artificial radiation. This laboriousness does not allow researchers to carry out thick sampling that we needed. The S-S technique, in which saturation value is taken from the natural saturated standard, is a significantly faster TL dating method keeping acceptable precision of measurement.

Dosimetric methods are usually tested by the most reliable radiometric dating. To test the S-S technique under conditions in Israel we chouse Lisan sediments in sections of Nahal Perazim that are situated, as well as the mouth portion of the Nahal Zin valley, in the southwest of the Dead Sea tectonic basin. In collaboration with the scientific group of M. Stein, we have collected samples from the PZ-2 section (Fig. 3). This section is correlated with the PZ-1 section dated by reliable U/Th method (Machlus et al., 2000).

Within the Lisan Formation, the first sampling was carried out in the part of the PZ-2 section where ages are correlated with the U/Th date of $66.89 \mathrm{Ka}$ at its bottom and $54.11 \mathrm{Ka}$ at the top (Machlus et al., 2000). The S-S dates of four samples in this part of the section are of $61.7 \pm 7.3$ to $53.2 \pm 4.6 \mathrm{Ka}$ The second sampling was carried out in the part of the PZ-2 section where ages are correlated with U/Th dates of 38.11 to $34.01 \mathrm{Ka}$. From the middle of this part of the section, we have received TL dates $31.4 \pm 1.8$ and $29.2 \pm 2.0 \mathrm{Ka}$ (Fig. 3).

At the top of the Samra formation a TL age of $81.7 \pm 16.2 \mathrm{Ka}$ was obtained in good agreement with the Lisan-Samra boundary, dated by U/Th to be about $70 \mathrm{Ka}$ BP (Kaufman, 1971; Kaufman et al., 1992; Stein, 1997). However, measurement of TL signals from sediments of the Samra Formation has showed that most samples were found by the S-S method to be saturated. It is caused by high background radiation, more than 25 microroentgen $/$ hour $(\mathrm{mr} / \mathrm{h})$, in the points of sampling. (In the case of a radiation dose of 5 to $10 \mathrm{mr} / \mathrm{h}$, the maximal age may be measured till 200 to $300 \mathrm{Ka}$; in the case of radiation dose of 10 to $15 \mathrm{mr} / \mathrm{h}$, the maximum age may be measured till 120 to $130 \mathrm{Ka}$. In the given case of very high radiation, the maximal age may be measured no more than $100 \mathrm{Ka}$ ). Nevertheless, potentialities for age diagnostic of the Lisan sediments by S-S technique are real-valued in any case.
On the whole, these sets of data confirm the validity of the ages in two modes: (a) an internal check - by each dating method the age is observed to be progressively younger upwards in the section; and (b) the values obtained by basically different methods, and by different laboratories, are in good agreement. However, some dispersion of data is observed, that is usual practice of dosimetric methods. The dispersion may be decline by both closer sampling and following correction of an overshooting with the help of statistic methods.

\section{Analysis of sedimentation environments in the Zin Valley}

Presence of lacustrine sediments included in terraces of the valley of lower Nahal Zin binds us to consider all possible causes of their deposition, and to exclude inappropriate phenomena. There are some sub-aquatic environments that may potentially permit deposition of fine laminate sediments under conditions of the Zin valley.

The first environment may be treated by water surface streams in the case of its damming. Great geological activity of the streams occurs everywhere in the region, and even at first glance it may seem that correspondence between the potential effect of the ephemeral streams and parameters of the Zin valley is violated. The reason is that the welldeveloped form characterizes the valley in spite of low precipitation feeding the streams.

It has been resulted that most geological work carries out during the flood period when power of the linear streams are very significant (Morin et al., 1998; Greenbaum et al., 2000). However, despite the ability of the streams to carry out great geological work, they have no water mass to fill and to keep a potential large stable lake in the valley because of very droughty climatic conditions in the region. The annual average precipitation thereof is less than $100 \mathrm{~mm}$ that is 20 times less than the annual average evaporation (Brawer, 1992). During the Quaternary the moisture balance did not change principally, although slight increase of precipitation entailed semiarid conditions at that time (Horowitz, 1979; Bar-Yosef and Kra, 1994). As to springs of underground water in the Zin valley, they are very rare and limited in resources. Another appreciable supply of water is absent there.

Thus, even in the case of damming the valley as a result of rock fall or another cause, accumulation of significant quantity of river water and its stable existence in the form of an inland lake is impossible in the Zin valley. However, it is fact that some of Pleistocene terraces in the valley are composed of lacustrine sediments that continuously extended from the Dead Sea tectonic basin, and form clear-shaped varves. The latter are presented with layers of alternating fine sands, and silts, and clays, in which aragonite and gypsum are contained as well as in the Lisan deposits. These lacustrine sediments in the Zin valley demonstrate their accumulation in an extensive and deep-water basin.

So, examination of all sedimentation environments, which may occur in the valley, shows that there is no cause of accu- 


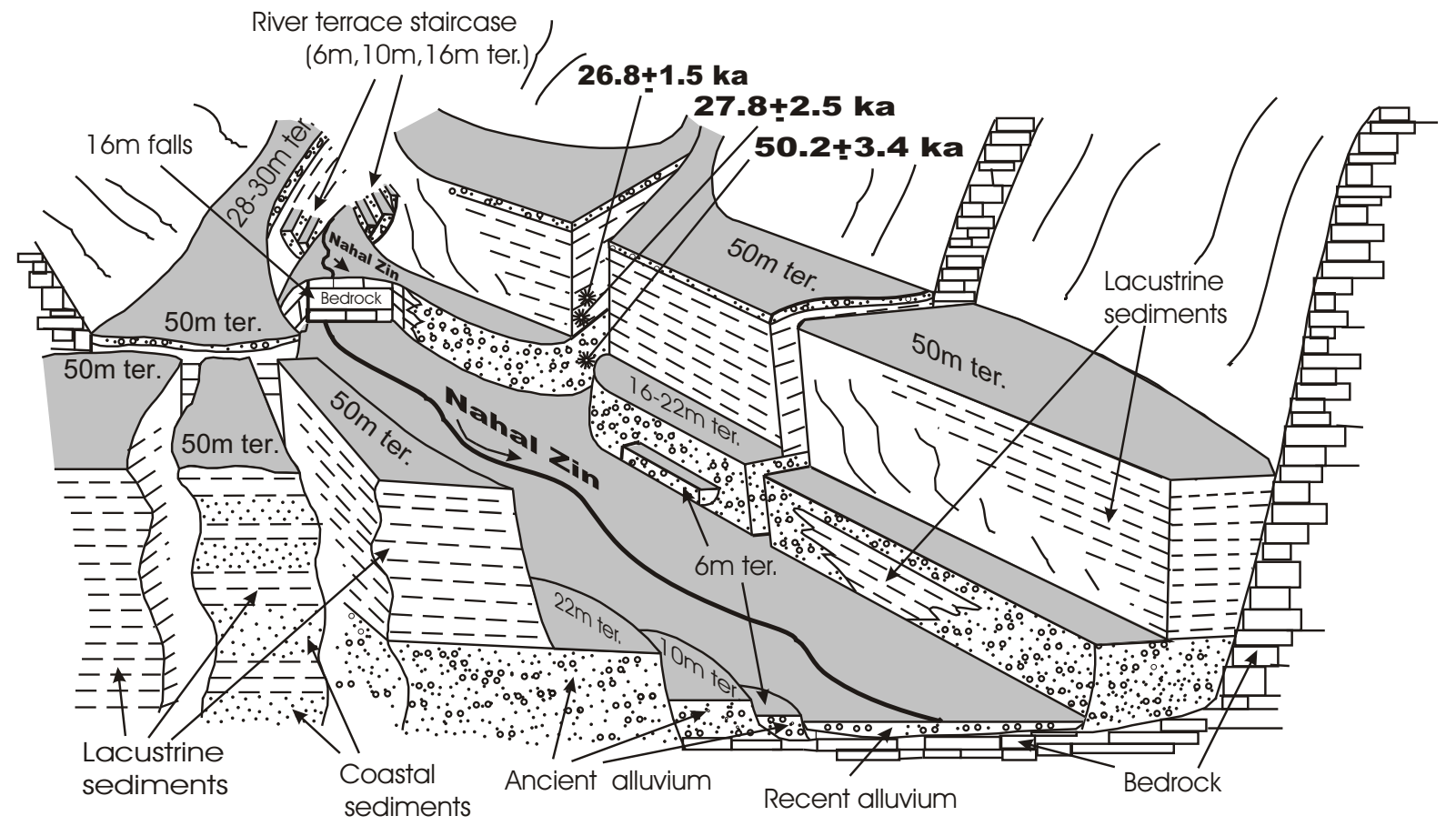

Fig. 4. A block-diagram demonstrating construction of the Zin valley near the Lower Zin Falls.

mulation of the lacustrine deposits there except of sedimentation within a bay that has to be extended from a lake in the Dead Sea tectonic basin. Only invasion of water from that lake was able to form and to keep a large and stable water basin in the Zin valley.

\section{Results and discussion}

\subsection{Nahal Zin in front of the Zin Gate}

In front of the Zin Gate, Nahal Zin cuts and reworks ancient lacustrine deposits of Palaeo-Dead Sea, which are still stretched from the terrain of the Dead Sea tectonic basin. A river terrace staircase consists of terraces at heights of 46 to $50 \mathrm{~m}$ at this site. Most of sections of the terraces are characterized by alternation of alluvial and lacustrine sediments. This alternation demonstrates coastal sedimentation environments that were typical within an area near the shoreline. Aside of the Zin valley, the alternating fluvial/lacustrine sediments are replaced by the Lake Lisan deposits that overlay the most bottom of Palaeo-Dead Sea. Lisan sediments are also observed at the foot of sections of young low (4 to $6 \mathrm{~m}$ ) terraces that are formed as a result of present-day incision of lower Nahal Zin into ancient deposits.

The body of the highest $50 \mathrm{~m}$ terrace is adjacent to the Zin Gate canyon where the riverbed is at $-230 \mathrm{~m}$ altitude. The surface of the terrace located at $-180 \mathrm{~m}$ altitude may be correlated with the traditional value of the maximal stand of Lake Lisan. However, the lacustrine deposits do not taper out at the steep of the fault escarpment. They continue to extent into the gorge-shaped valley, and also to rise.
5.2 Nahal Zin between the Zin Gate and the Lower Zin Falls

A block-scheme demonstrating construction of the valley for the $2 \mathrm{~km}$ reach between the Zin Gate and the Lower Zin falls is shown on Fig. 4. In comparison with the same terraces in front of the Zin Gate, composition of river terraces located upstream of it changes sharply. The $50 \mathrm{~m}$ terrace continues to be expressed as an element of relief upstream of the Zin Gate. However, lacustrine deposits, included in it, represent undivided thick horizons, rather than alternating fluvial-lacustrine layers. This stands for development of these horizons under continuous lake sedimentation environments. As well as the typical Lisan sediments, the lacustrine deposits located upstream of the Zin Gate consist periodically of aragonite and gypsum.

Most sections of the $50 \mathrm{~m}$ terrace represent two-level construction (Fig. 4). The lower part of the terrace is composed of 16-22 $\mathrm{m}$ thick alluvium that serves as the base of the twolevel construction. The upper part represents $28-30 \mathrm{~m}$ thickness composed of mainly lacustrine sediments.

Sometimes, the upper horizon of the lacustrine sediments is removed by erosion, and another $16-22 \mathrm{~m}$ cut terrace is formed. (A height of the cut terrace near the Zin Falls is of $16 \mathrm{~m}$, and it is raised to $22 \mathrm{~m}$ near the Zin Gate). In this case, sections of the lacustrine sediments, overlaying the alluvial base, are raised a few tens of meters aside of the edge of the 16-22m terrace (Fig. 4). The cut terrace is composed of pebble-gravel material, and conjugated with the rocky body of the Lower Zin Falls. Erosion genesis of the 16-22 m terrace is confirmed by construction of sections in the valleys of 
tributaries that flow into Nahal Zin downstream of the Lower Zin Falls. The tributaries cut the $50 \mathrm{~m}$ thickness as a whole, and the two-tiered construction in the formed sections is also observed. The layers of the alluvial bases stretch into the valleys of the tributaries where they underlie the lacustrine deposits (Fig. 4).

Origin of the $16-22 \mathrm{~m}$ terrace, which is cut out the $50 \mathrm{~m}$ terrace, is a result of a delay in incision of Nahal Zin into the $50 \mathrm{~m}$ thickness during a retreat of the maximal lake. Coincidence of both the surface of the 16-22 $\mathrm{m}$ terrace and the surface, which divides the $50 \mathrm{~m}$ thickness into two parts, is random in this case.

We have carried out TL dating of both alluvial and lacustrine horizons of the $50 \mathrm{~m}$ terrace TL age of the alluvial base is of $50.2 \pm 3.4 \mathrm{Ka}$. At the bottom of the lacustrine horizon TL ages are of $26.8 \pm 1.5$ and $27.8 \pm 2.5 \mathrm{Ka}$ (Fig. 4). The ages indicate that deposition of the lacustrine sediments occurred during the maximal stand of Lake Lisan, which is established (Bartov et al., 2000) as correlated with the marine isotope stage 2 . Before this time, alluvial deposits were only accumulated in the valley of lower Nahal Zin upstream of the Zin Gates.

The base of the Lower Zin Falls is at an altitude of $-215 \mathrm{~m}$, and its edge is at an altitude of about $-200 \mathrm{~m}$. Downstream, bedrocks covered by thin and rare alluvium present the riverbed of the main valley. Particular features of the initial relief excavated after Lake Lisan regression may explain this construction of the valley.

The Lower Zin Falls are developed when Nahal Zin has cut a new channel because the Lisan deposits, which are presented as the 28-30 horizon of the $50 \mathrm{~m}$ thickness, have buried the former channel. It occurred after the discharge of the lake invaded into the Zin valley during the highest stand of Lake Lisan. At first, Nahal Zin has excavated hard rocks of its right-hand slope, and, during a delay in incision, formed the surface of the 16-22 m terrace. Later on, a new phase of incision triggered by lowering the base level of erosion took place. Regressive erosion has reached this site, and the erosion process met with an obstacle of hard rocks in the Post-Lisan valley, and made for development of the falls.

At present, deposits of the buried valley are exposed and well observed in sections of the valley of the left-hand Zin tributary that flows into the main valley near the Lower Zin falls. Incision of the tributary in the loose rocks of the former Zin valley caused development of a narrow ravine, rather than falls.

Not far from the Zin Gate, a bowl-shaped thickness of lacustrine sediments is inset into the pebble-gravel body of the cut terrace that reaches a height of $22 \mathrm{~m}$ there (Fig. 4). It may be, probably, a result of filling the channel of a tributary that was cut into pebble-gravel alluvium of the $16-22 \mathrm{~m}$ terrace. This phenomenon may be occurred during one of the late fluctuations of Lake Lisan.

Post-Lisan formations are also expressed within described portions of the Zin valley. They compose of young terraces at heights of 4 to $6 \mathrm{~m}$, which leaned on the $16-22 \mathrm{~m}$ terrace, and differ from it in coarser pebble-gravel material.
5.3 Nahal Zin between its confluence with Nahal Hazera and the Lower Zin Falls

Over the most portion of the $1.5 \mathrm{~km}$ reach between the Hazera mouth and the Lower Zin Falls, Nahal Zin flows in the Post-Lisan valley. It differs from the preceding portion by change in the terrace staircase.

A level, which characterized the surface of the $50 \mathrm{~m}$ terrace of the preceding valley portion, continues to be expressed as before, but a height of the terrace decreases to 28-30 m (Fig. 4). This terrace also consists of lacustrine deposits that are stretched continuously from the $50 \mathrm{~m}$ terrace, kept as a single undivided horizon, and overlaid on the alluvial base. However, thickness of the lacustrine horizon decreases to $10-15 \mathrm{~m}$, and thickness of the alluvial base decreases to $10-12 \mathrm{~m}$. Usually, a few meters cover of younger alluvium overlie on the lacustrine sediments at the top of the 28-30 m terrace.

Another terrace consisted of lacustrine sediments is at a height of $16 \mathrm{~m}$. It also represents a $10-12 \mathrm{~m}$ alluvial base that is covered by $4-6 \mathrm{~m}$ horizon of the lacustrine sediments. The same material of the bases both in the $16 \mathrm{~m}$ and $28-30 \mathrm{~m}$ terraces, and the same level of occurrence of the lacustrine sediments in these terraces, and continuity in extension of these sediments stand for creation of the $16 \mathrm{~m}$ terrace by cutting out the higher $28-30 \mathrm{~m}$ terrace.

Lower terraces $(6 \mathrm{~m}$ and $10 \mathrm{~m})$ are also included in the river terrace staircase. However, they do not consist of lacustrine sediments (Fig. 4), and are a result of only river erosionaccumulative activity.

The confluence of Nahal Zin with Nahal Hazera is at an altitude of $-180 \mathrm{~m}$. The uppermost position of the lacustrine sediments belonging to the $28-30 \mathrm{~m}$ terrace is at an altitude of $-150 \mathrm{~m}$ at this site. Perceptible evidence of tectonic disturbance causing elevation of the terrace sediments is not revealed there. Anyway, the noted level is steel correlated with other values of higher stands of Lake Lisan than the traditional value of $-180 \mathrm{~m}$ (Clark, 1988; Bowman and Gross, 1992).

\subsection{Nahal Hazera between its confluence with Nahal Zin} and the Hazera Falls

The reach of the valley of Nahal Hazera between its confluence with Nahal Zin and the Hazera Falls is stretched for a distance of $1.5 \mathrm{~km}$. A scheme of construction of this reach is shown on Fig. 5. This valley portion is similar to the preceding reach in features of the river terrace staircase when only sections of the terraces at a height of $16 \mathrm{~m}$ and $28-30 \mathrm{~m}$ consist of lacustrine sediments. The distinction is an increase of the $28-30 \mathrm{~m}$ terrace in height to $32 \mathrm{~m}$, and tapering out this terrace near the Hazera Falls. It does not occur upstream of the falls. Sometimes 3-7 m layer of alluvium replaces the top part of the lacustrine sediments included in this terrace. The reason of the increase in height of the terrace is that the Hazera valley is narrow. Concentration of debris material, which 


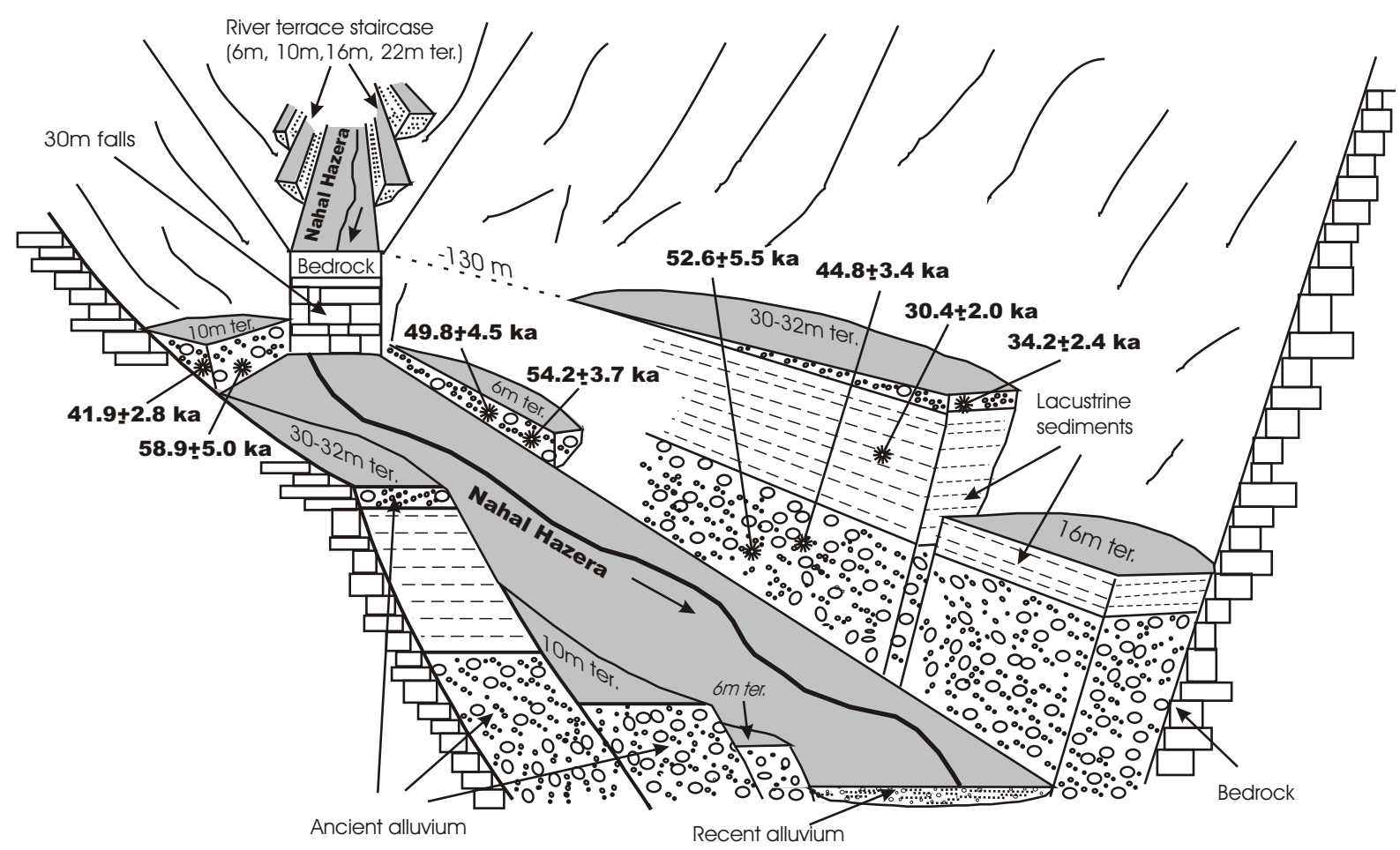

Fig. 5. A block-diagram demonstrating construction of the Hazera valley near the Hazera Falls.

came from slopes to the former floor of the valley, and fed the alluvial deposits, provides the increase in a height.

The foot of the Hazera Falls is at an altitude of $-160 \mathrm{~m}$, and its edge is conjugated with the surface of the $32 \mathrm{~m}$ terrace (Fig. 5). The overhang of the falls is composed of hard carbonate rocks that are not covered with alluvium. The uppermost lacustrine sediments, which continue to stretch as a single horizon from downstream, reach an altitude of $-130 \mathrm{~m}$ near the Hazera Falls where they are tapered out.

In the best way, the section of the $32 \mathrm{~m}$ terrace is observed at the site $400-500 \mathrm{~m}$ downstream of the Hazera Falls where the terrace is composed of the following horizons:

1. Upper horizon: $5-7 \mathrm{~m}$; coastal deposits, composed of well-laminated gravel and sand.

2. Middle horizon: $12-15 \mathrm{~m}$; lacustrine silt, clay and fine sand, forming distinct varves.

3. Bottom horizon: 10-12 m; coarse-grained alluvial deposits, including well-rounded boulders.

We have carried out TL dating of the horizons. The alluvial material at the bottom of the section yielded the TL ages of $52.6 \pm 5.5$ and $44.8 \pm 3.4 \mathrm{Ka}$. The TL age of $30.4 ? 2 \mathrm{Ka}$ was obtained for the sample from the central part of the lacustrine horizon (Fig. 5). However, age of the sample from alluvium at the top of the terrace section turned out of $34 \pm 2.4 \mathrm{Ka}$. This inversion may be explained by impossibility to remove contamination in this sample, and it gave us the age determination a little more than in the central part of the section. Any- way, the dating demonstrates age of the lacustrine horizon as of about $30 \mathrm{Ka}$.

On the whole, the obtained ages reveal the systematic trend of age decrease upwards, indicating an orderly accumulation history and providing an internal check for the validity of the data. The age of about $30 \mathrm{Ka}$ of the lacustrine sediments, as well as the same ages obtained from the lacustrine horizon of the $50 \mathrm{~m}$ terrace near the Lower Zin Falls, agrees with the age of the maximum development of Lake Lisan, which, according to recent data, is assigned at $27 \mathrm{Ka}$ (Bartov et al., 2000). The ages of the alluvial bases of both terraces are also in good agreement.

As well as within the preceding portion of the Zin valley, perceptible evidence of tectonic disturbance, which could be a cause of elevation of the terrace sediments, is not revealed in the valley of lower Nahal Hazera. We do not exclude possibility that a series of micro-upheavals, which may be revealed by a special research (we plan this research in future), provided so high location of the lacustrine sediments. Anyway, the findings left by the Zin estuary of Lake Lisan disclose that the level of the lake could reach the edge of the Hazera Falls, the present-day location of which is at a height of $-130 \mathrm{~m}$.

Two terraces more are observed near the Hazera Falls, and are of special interest. These are the terraces at a height of 6 and $10 \mathrm{~m}$. Their sediments bury the foot of the Hazera Falls, and hence, the falls pre-dates them. We have carried out TL dating of both terraces. The TL ages of $41.9 \pm 2.8$ to $58.9 \pm 5.0 \mathrm{Ka}$, found for the bottoms of these lower terraces, overlap with the ages of $44.8 \pm 4.5$ to $52.6 \pm 5.5 \mathrm{Ka}$ obtained 
at the bottom of the $32 \mathrm{~m}$ terrace (Fig. 5), and with the age of $50.2 \pm 3.4 \mathrm{Ka}$ received for the alluvial base of the $50 \mathrm{~m}$ terrace near the Lower Zin Falls. This leads to the conclusion that the bottom of both the $32 \mathrm{~m}$ terrace and the lower $(6 \mathrm{~m}$ and $10 \mathrm{~m})$ terraces near the Hazera Falls, and also the $50 \mathrm{~m}$ terrace near the Lower Zin Falls, are built of the same sediments, and, hence, the $6 \mathrm{~m}$ and $10 \mathrm{~m}$ terraces are truncated remains of the $32 \mathrm{~m}$ terrace.

Near the confluence of Nahal Hazera with Nahal Zin, the $16 \mathrm{~m}$ terrace is well expressed, and reveals at its base alluvium that resembles the sediments at the base of the $32 \mathrm{~m}$ terrace. A horizon of partially eroded lacustrine sediments occurs at the top of the $16 \mathrm{~m}$ terrace (Fig. 5). These are absent from the section of the adjacent $6 \mathrm{~m}$ and $10 \mathrm{~mm}$ terraces, and it suggests, thus, that erosive stripping of the $32 \mathrm{~m}$ terrace also formed the $16 \mathrm{~m}$ terrace.

As to the Hazera Falls, they were formed by regressive erosion of Nahal Zin not only before the invasion of water from Palaeo-Dead Sea into the Zin valley. The falls were raised even before deposition of the base alluvium of the erosion terraces, i.e. before than $60 \mathrm{Ka}$. Upstream of the falls, the river terrace staircase consists of a few units $(6 \mathrm{~m}, 10 \mathrm{~m}$, $16 \mathrm{~m}$ and $22 \mathrm{~m}$ terraces) that are devoid of lacustrine sediments (Fig. 5).

\subsection{Nahal Zin between its confluence with Nahal Hazera} and the Upper Zin Falls

The distinguishing feature of the valley of Nahal Zin, as well as of lower Nahal Hazera, upstream of their confluence is presence of the $28-30 \mathrm{~m}$ terrace consisting of the well expressed lacustrine sediments. On the whole, the terrace staircase of this valley portion is similar to that occurred in the valley of lower Nahal Hazera.

In the best way, construction of the $28-30 \mathrm{~m}$ Zin terrace consisting of the lacustrine sediments is observed $1 \mathrm{~km}$ upstream of the Hazera mouth. A right-hand tributary of Nahal Zin cuts the terrace, and discloses all its features. Thickness of alluvial base of the terrace is of 10 to $12 \mathrm{~m}$. The lacustrine deposits overlaying this base compose of the rest part of the terrace section.

The foot of the terrace is at $-160 \mathrm{~m}$ altitude. The uppermost layers of the lacustrine horizon reach also a height of about $-130 \mathrm{~m}$. TL dating of the terrace gave us the result that is similar to those of the $32 \mathrm{~m}$ terrace in the valley of lower Nahal Hazera. The TL age of the top of alluvial base of the terrace is determined as $36.9 \pm 3.4 \mathrm{Ka}$. This allows us to consider the lacustrine sediments overlaid on the alluvial base as deposed during the maximal stage of the Lake Lisan.

Upstream of the mouth of the noted Zin tributary, well expression of the lacustrine sediments is observed in the Zin valley for about $2 \mathrm{~km}$. Still upstream, till the Upper Zin Falls, the most lacustrine deposits included into the $28-30 \mathrm{~m}$ terrace are stripped and replaced by alluvium. Although, these alluvial sediments (sand, fine gravel and pebbles) are well laminated, and may be identified as deposits of the former coastal zone. At that, the sediments indicating coastal envi- ronment of their deposition are raised up to $-120 \mathrm{~m}$ altitude. The latter is a height of the overhang of the Upper Zin Falls. Thus, in front of the Upper Zin Falls, for a distance of $3 \mathrm{~km}$ there are not conserved blocks of undivided lacustrine horizons a few meters thick. However, position of the uppermost lacustrine sediments in the Zin valley (at a height of $-130 \mathrm{~m}$ ) suggests extention of the Zin estuary of Lake Lisan till the Upper Zin Falls, the upper surface of which has an altitude of $-120 \mathrm{~m}$.

Are these deposits raised by tectonic elevation or not? As well as in the case of the Hazera valley, we do not exclude an influence of tectonic processes. However, in the meantime this question is still an open question.

In any case, it has been supposed that Lake Lisan reached an altitude of $-150 \mathrm{~m}$ at least. The lacustrine sediments located within the upper reach of the former Lake Lisan estuary could be elevated to the present-day $-130 \mathrm{~m}$ altitude under tectonic effect. However, this is one of the probable scenarios of development of the valley.

Another scenario may be made up to explain a difference in declivity of the top surface of the Lisan horizon. Within the valley reach between the Zin Gate and the Hazera-Zin confluence, the declivity is of about $12 \mathrm{~m} / \mathrm{km}$. Upstream of the confluence, in the Hazera valley, the declivity increases to $13 \mathrm{~m} / \mathrm{km}$, but in the Zin valley it decrease to $7-8 \mathrm{~m} / \mathrm{km}$. Such position of the top surface of the Lisan horizon may not be explained by its tectonic elevation, in the case of which the declivity should be the same in both valleys upstream of the confluence. This stands for clothing the Pre-Lisan Zin valley in the lacustrine sediments, which repeat by its shape the origin riverbed, during the highest stage of Lake Lisan when the sediments may reach $-130 \mathrm{~m}$ altitude.

\section{Conclusion}

1. Lakes, which may be developed within the Dead Sea tectonic basin, are like the lungs that breathe according the rhythmic climate change. Evolution of these is a controlling factor of development of the valleys that runs to this basin from the Negev Highlands. Presence in the valleys of lacustrine sediments, which are unified as Lisan Formation, serve as fixed points that enable us to study the valley development in the next details:

(a) An influence of Lake Lisan that invaded into the ancient gorges around the Dead Sea tectonic basin during the highest stage 20 to $30 \mathrm{Ka}$ ago, and left its sediments up to an altitude of $-130 \mathrm{~m}$.

(b) Possibility of re-elevation of the Lisan sediments located significantly higher than the revealed within the Dead Sea tectonic basin.

(c) Conservation and re-formation of the relief of the Pre-Lisan landscape.

(d) Re-working the ancient relief following the recession of Lake Lisan, and development of the PostLisan landscape. 
2. Identification of river terraces of the valley of lower Nahal Zin, the absolute dating of their alluvial and lacustrine horizons, and the research of the composition of these horizons provide powerful tools to study the late stages of evolving nature of Lake Lisan.

3. Further study of Palaeo-Dead Sea estuaries requires carrying out the large-scale mapping and creation of detailed geomorphologic profiles within the lower reaches of the valleys running to the Dead Sea.

4. Specific research problems include the means for tackling one of the fundamental questions: what events defined peculiarities of the fluctuations of Lake Lisan?

\section{References}

Bartov, Y., Agnon, A., Enzel, Y., Reches, Z., and Stein, M.: Reconstruction of Lake Lisan levels by sequence stratigraphy of shore and lacustrine sediments at Massada, in: Baer, G. and Avni, Y. (Eds.): Israel Geol. Society, Annual meeting, 2000, Abstracts, 16 pp, 2000.

Bar-Yosef, O. and Kra, R. S. (Eds): Late Quaternary chronology and paleoclimates of the Eastern Mediteranian. Radiocarbon, Dept. of Geosc., Univ. of Arizona, Tucson, Arizona, 371pp, 1994.

Begin, Z. B., Ehrlich, A., and Nathan, Y.: Lake Lisan. The Pleistocene precursor of the Dead Sea, Geol. Survey of Israel, Bulletin No. 63, Jerusalem, 30pp, 1974.

Begin, Z. B., Broecker, W., Buchbinder, B., Druckman, Y., Kaufman, A., Magaritz, M., and Neev, D.: Dead Sea and Lake Lisan levels in the Last 30000 years - A prelim. rep. Geol. Surv. of Isr., GSI/29/85, 18pp, 1985.

Bowman, D. and Gross, T.: The highest stand of Lake Lisan: $150 \mathrm{~m}$ below MSL, Isr. Jour. of Earth Sc., 41, 233-237, 1992.

Brawer, M. (Ed.): The New Israeli University Atlas, "Yavneh" Publishing House Ltd., Tel Aviv, 192pp, 1992.

Clark, G. A.: Some thoughts on the southern extent of the Lake Lisan as seem from the Jordan side, Bul. Of the American School of Oriental Research, 272, 42-43, 1988.

Greenbaum, N., Shick, A. P., and Baker, V. R.: The palaeoflood record of a hyperarid catchment, Nahal Zin, Negev Desert, Israel, Earth Surf. Process. Landforms, 25, 951-971, 2000.

Horowitz, A.: The Quaternary of Israel, Academic Press, New York and San Francisco, 394pp, 1979.

Kaufman, A.: U-series dating of the Dead sea Basin carbonates, Geochemica et Cosmochemica Acta, 35, 1269-1281, 1971.
Kaufman, A., Yechieli, Y., and Gardosh, M.: Re-evaluation of the lake-sediment chronology in the Dead Sea basin, based on new 230 Th/U dates, Quaternary Research, 38, 292-304, 1992.

Machlus, M., Enzel, Y., Goldstein, L., Marco, S., and Steim, M.: Reconstructing low levels of Lake Lisan by correlating fan-delta and lacustrine deposits, Quaternary international, 73/74, 137144, 2000.

Morin, J., Sharon, D., and Rubin, S.: Rainfall intesity in Israel. Revised version of Research report 1/94, Bet Dagan, 148pp, 1998.

Neev, D. and Emery, K. O.: The Dead Sea. Depositional processes and environments of evaporates, Geol. Survey of Israel, Bulletin No. 41, Jerusalem, 1967.

Neev, D. and Hall, D.: Climatic fluctuations during the Holocene as reflected by the Dead Sea levels, in: Greer, D. (Ed.): Desertic terminal lakes, Utah State Univ., Logan, 53-60, 1977.

Niemi, T. M., Ben-Avraham, Z., and Gat, J. R. (Eds.): The Dead Sea. The Lake and its setting, Oxford Univ. Press, New York and Oxford, 1997.

Shlukov, A. I., Usova, M. G., Voskovskaya, L. T., and Shakovets, S. A.: New absolute dating techniques for Quaternary sediments and their application on the Russian Plain, in: Bruns, P. and Hass, H. C. (Eds.): Determination of sediment accumulation rates, GeoResearch Forum, 5, Trans Tech Publications, Switzerland, 145-168, 1999.

Sheinkman, V.: Evolution of the Dead Sea basin and Lisan invasion into Lower Nahal Zin. The First Mueller conference of the European Geophysical Society, Deaf Sea, Israel, 51pp, 2000a.

Sheinkman, V.: Lisan invasion and re-formation of the Lower Nahal Zin river system, Israel Geological Society, Annual Meeting 2000, Ma'a lot, 114pp, 2000 b.

Sheinkman, V. S. and Shlukov, A. I.: Experimental age determination of the Lisan sediments by speeded-up technique of TL dating (S-S method), Israel Geol. Soc., Annual meeting 2001. Abstracts, 110pp, 2001.

Stein, M., Starinsku, A., Katz, A., Goldstein, S. L., Machlus, M., and Schramm, A.: Strotium isotopic, chemical, and sedimentological evidence for the evolution of Lake Lisan and the Dead Sea, Geochemica et Cosmochemica Acta, 61 (18), 3975-3992, 1997.

Wintle, A. G. (Ed.): Luminescence and ESR dating and allied research, Radiation Measurements, Special Issue, 27 (5/6), $1025 p p, 1997$.

Yechieli, Y., Magaritz, M., Levy, Y., Weber, U., Kafri, U., Woelfli, W., and Bonani, G.: Late Quaternary Geological History of the Dead Sea Area, Israel, Quater. Research., 39, 59-67, 1993.

Yechieli, Y., Gavrieli, I., Bercowitz, B., and Ronen, D.: Will the Dead Sea die? Geology, 26 (8), 755-758, 1998. 